\title{
ADVANCEMENTS IN BANKING SECTOR AND DEVELOPMENT OF INDIA
}

\author{
Sneha Barua \\ Department of Commerce \\ Symbiosis Center for Management Studies, Pune, \\ Maharashtra, India
}

\begin{abstract}
The banking sector plays a vital role in the development of a country's economy. Our country India is quite efficient in this sector as it tackled the pressure during the Global Financial Crisis 2008. The objective of this research article is to study the growth in the Indian Banking Sector since 1990s, which majorly happened because of the technological Innovation \& computerization in the Indian Banking Sector. Without the innovation in technology, banking sector would not flourish so much as it is today. Effective $\&$ wise use of technology has multiple effects on the growth $\&$ development of the country. The growth of banking sector depends upon the services \& facilities provided by the banks to the customers. The growing trends of banking services is found significant after the new economic reforms in India. Advancements in Banking Sector has increased access of banking system \& made even small to minor transactions possible. Technology has allowed transactions to happen smoothly $\&$ efficiently and is able to carry out transactions which led to the growth \& diversification of banking sector. It acts as the backbone of Indian Economy which is evident especially during the period of boom $\&$ recession. From the year 1991 various trends \& developments have been taking place, which also reflects the various reforms that were caused to improve the working of their system to satisfy the customer by better services $\&$ facilities.
\end{abstract}

Keywords—Banking sector, Development, Technology

\section{INTRODUCTION}

Banking in India originated in the first decade of the $18^{\text {th }}$ century. The first banks were The General Bank of India, which started in 1786, and Bank of Hindustan, both of which are no more in function. At the end of late-18th century, there were very few banks functioning in India. The actual need arose when the American Civil War stopped the supply of cotton to Lancashire from the Confederate States. So, the promoters opened banks to finance trading in cotton. Since then banking in India remained the exclusive domain of Europeans for several decades until the beginning of $20^{\text {th }}$ century. Growth and diversification in banking sector has outranked limits all over the world. Banks are the major segment of the financial sector in India, which underwent reform measures that primarily aimed at improving the performance of the banking sector. An efficient banking system has significant positive advantages, which increases the efficiency of economic transaction in general. The Indian Government took major step in the year 1969 to put the banking sector into systems and it nationalized 14 private banks in that particular year. This has been elaborated in Nationalization Banks in India. The advancements in banking sector in India is majorly due to the technological advancements that took place during the late 90s.Our country India has a fairly well developed system of banking with different types of banks such as public sector banks, foreign banks, private sector banks - both old and new generation, regional rural banks and co-operative banks with the Reserve Bank of India as the central Head of the system. The banking system in India is significantly different from other Asian nations because of the country's distinctive geographic, social, and economic characteristics. Today Indian banking Sector is a prospering Industry which is majorly focused on new Banking Technological innovations. Banks initiated the usage of technology to provide effective quality and services to its customers. In the recent scenario has been changed, there are around 340 banks are working in India, in which are public and private banks. Today all the banks started with the different modes, like ATM, Credit Cards, Debit Cards, Mobile Banking, Internet Banking, etc. But Net Banking made it easier for customers to do their banking transaction from various places. In 2020 India's banking sector will be the fifth largest banking sector and by the year 2025 the Indian banking system will be the third largest banking sector in the world. The Indian Banking System cannot disregard the new technological challenges that took place in the recent years and that the banks are also facing great challenges with regards to innovations policy and strategy.

\section{Research METHOdOLOGY}

This paper is based on several secondary sources such as published journals, articles and newspapers. Websites and 


\section{International Journal of Engineering Applied Sciences and Technology, 2019 \\ Vol. 4, Issue 6, ISSN No. 2455-2143, Pages 158-162 \\ Published Online October 2019 in IJEAST (http://www.ijeast.com)}

conference publications have also been used in order to make this paper more credible and authentic.

\section{HISTORY}

The pre- independence period was largely characterized by the existence of private bank organized as joint stock companies. Most banks were small and had private shareholding of the closely held variety. They were largely localized and many of them failed. The period beginning from 1967 to 1991 was characterized major development, namely social control on banks in 1967 and nationalization of 14 banks in 1969 and 6 more in 1980.

The banking sector was developed during the British Era. British East India Company established three banks under it namely- Bank Of Bengal 1809, Bank Of Bombay 1840, Bank Of Madras 1843. These three banks were later amalgamated and was known as The Imperial Bank, which was taken over by SBI in the year 1955. The Reserve Bank Of India was established in 1935, followed by The Punjab National, Bank Of India, Canara Bank and Indian Bank. ${ }^{1}$

Indian Banking System has gone through various phases over the years which can be broadly classified as follows:

\section{- $\quad$ Early Phase (1786-1935)}

In this face the growth was very slow and the banks experienced periodic failures. There were around 1100 banks mostly small which failed during this phase.

\section{- $\quad$ Pre- Nationalization (1935-1969)}

To maintain the monetary stability in India, Reserve Bank Of India came into existence. This phase of Indian Banking was eventful and was a phase of restructuring regulations. However despite these provisions, control and regulations, banks in India except the State Bank Of India, continued to be owned and operated by private persons.

$\bullet$

Post Nationalization (1969-1990)

This phase of Indian Banking did not have any new entry of banks. Undoubtedly it was a phase of expansion, consolidation and increment is various aspects. The banking sector grew at a tremendous rate and, fruits of nationalization were evident and the common man was banking with great trust.

\section{- $\quad$ Modern Phase (1990- present)}

This is the generation of new tech-savy banks and is also known as the "Reforms Phase". At present, banking in India is fairly doing well in terms of supply, product range and resch. Though its reach to rural areas is still a challenge for the private sector and foreign banks

\section{PRIVATIZATION OF BANKING SECTOR}

Privatization is transfer of ownership from the public to the private sector as well as the control over assets ${ }^{2}$. Privatization increases competition within the banking sector which results in better facilities and increase the varieties of facilities. In the year 1947, India gained independence and became independent. Therefore, the economy gained liberalization. Be that as it may, at the time, the assumed achievement of the Soviet Model of financial improvement over the Capitalist Model drove the policymakers to take after a communist way with arranged advancement ${ }^{3}$.

Enhancing the efficiency of the banking sector has been the main aim of any economic reform. Accordingly, the Indian government started diluting its equity in PSBs from early 1990 s in a phased manner. ${ }^{4}$

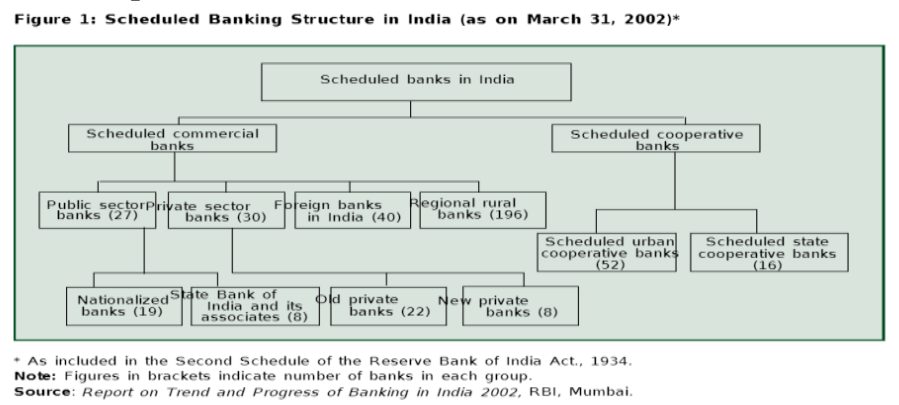

As per the graph above, the private sector bank owns approximately $80 \%$ of the banking units. 5 This indicates that the banking sector has grown over the years in terms of geographical coverage, credit expansion and deposit facilities. While at the end of 1964, only 10 per cent of the commercial banks were located in the rural areas, the proportion stood at 40 per cent by 2002.6 Since 1990 's, the government has implemented several banking reforms such as lowering the statutory liquidity ratio and cash reserve ratio.

SLR Rate, CRR Chart

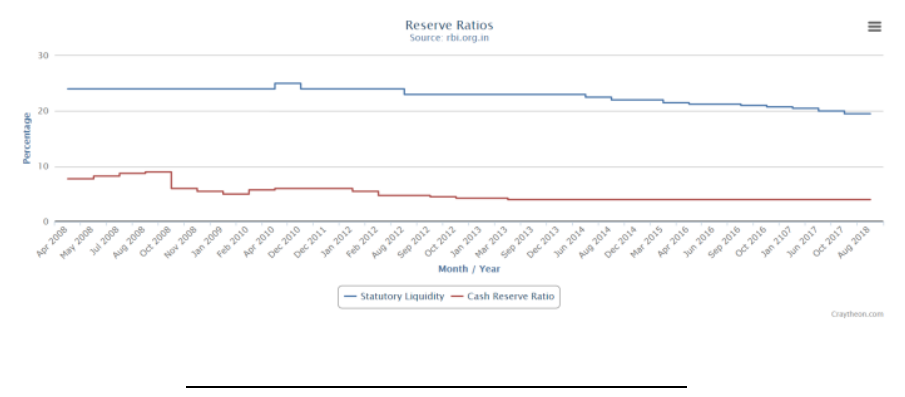




\section{International Journal of Engineering Applied Sciences and Technology, 2019 \\ Vol. 4, Issue 6, ISSN No. 2455-2143, Pages 158-162 \\ Published Online October 2019 in IJEAST (http://www.ijeast.com)}

As per the graph, the SRL rate has been decreasing together with CRR rate. Banks in India are required to hold a certain proportion of their deposits in the form of cash. However Banks don't hold these as cash with themselves, they deposit such cash (aka currency chests) with Reserve Bank of India, which is considered as equivalent to holding cash with them. This minimum ratio (that is the part of the total deposits to be held as cash) is stipulated by the RBI and is known as the CRR or Cash Reserve Ratio. This allows India to control the liquidity system.

Every bank is required to maintain at the close of business every day, a minimum proportion of their Net Demand and Time Liabilities as liquid assets in the form of cash, gold and un-encumbered approved securities. The ratio of liquid assets to demand and time liabilities is known as Statutory Liquidity Ratio (SLR). RBI is empowered to increase this ratio up to $40 \%$. An increase in SLR also restricts the bank's leverage position to pump more money into the economy.

The objectives of lowering the SLR are:

- To prevent the banks from over
liquidating

- To control the bank credit during various economic stages

Within the Indian banking sector, several banks are operating as private-public partnership. There were close to 27 public banks, 23 private banks, and 23 foreign banks in the year 1990-91, right before the economic reforms. The major role played by these banks is to help the economic growth where most of the shares were controlled by the government. Liberalization came into the picture and there occurred a major change in the banking sector which several new policies and reduction in the level of bureaucracy. Their main role is to assist the overall economic growth where majority of shares being controlled by the government of India. But when the liberalization takes place, the banking industry undergone tremendous change in the last 5years.

New RBI guidelines:

After the economic liberalization, the RBI issues several new guidelines in order to adjust to the reforms and help India's Economy Grow. Some of the major guidelines include:

- Paid-Up Capital - The new banks should maintain initial minimum paid up capital Rs.100crores. within 3years of commencement of business banks should raise initial capital to 300 crores. $^{7}$ Under this policy, the promoters investment should be $40 \%$ of the paid up capital at any time. This will be locked in for 5 years. The foreign investment will also be limited to $40 \%$
- Banks Promoted by Large Industrial Houses ${ }^{8}$ : Participation of the individual companies are allowed up till $10 \%$ in the equity of the bank. There is further a minimum requirement of the bank to keep a minimum capital of $10 \%$ before the commencement.

Privatization of the banking sector has helped the economy in several ways such as:

There will be reduction in the government controls over the banks which leaves space for innovation and new ideas in the sector. The main aim of the any private sector is maximization of profits and will foster technological developments which lead to greater innovations and a large variety of facilities for the customers.

\section{THE DEVELOPMENT OF THE BANKING SECTOR}

In a highly digitalized and technologically advanced world, technology has been incorporated in every aspect of operation and the banking sector have adapted to this. There are several service are available anywhere in any part of the world and can be accessed by anyone. Due to the online platform and globalization, there number of services and credit facilities has grown exponentially with a large pool of choices.

\section{1) Electronic Payment Services - E Cheques}

The usage of e-governance, e-mail, e-commerce, e-tail etc. have become so common these days, in the same manner, a new technology is being developed in US for introduction of e-cheque, which will eventually replace the conventional paper cheque. India, as an indicator to the introduction of echeque, the Negotiable Instruments Act has already been amended to include; Truncated cheque and E-cheque instruments.

\section{2) Real Time Gross Settlement (RTGS)}

Real Time Gross Settlement system, introduced in India since March 2004, is a system where transfer of funds takes place on a real time basis. The RTGS system is operated and maintained by the RBI and provides a means of efficient and faster funds transfer among banks facilitating their financial operations. As the name suggests, funds transfer between banks takes place on a 'Real Time' basis. Therefore, money can reach the beneficiary instantly and the beneficiary's bank has the responsibility to credit the beneficiary's account within two hours.

\section{3) Electronic Clearing Service (ECS)}

Electronic Clearing Service is a retail payment system that can be used to make bulk payments/receipts of a similar nature from one bank account to another.This facility is meant for companies and government departments to make large 


\section{International Journal of Engineering Applied Sciences and Technology, 2019 \\ Vol. 4, Issue 6, ISSN No. 2455-2143, Pages 158-162 \\ Published Online October 2019 in IJEAST (http://www.ijeast.com)}

amounts of payments rather than for funds transfers by individuals. Electronic Clearing Service can be used for both credit and debit purposes.

\section{4)Electronic Funds Transfer (EFT)}

Electronic Funds Transfer (EFT) is a system whereby anyone who wants to make payment to another person or a company etc. can approach his bank and make cash payment or give instructions/authorization to transfer funds directly from his own account to the bank account of the receiver/beneficiary. Complete details such as the receiver's name, bank account number, account type (savings or current account), bank name, city, branch name etc. should be furnished to the bank at the time of requesting for such transfers so that the amount reaches the beneficiaries' account correctly and faster. RBI is the service provider of EFT.

\section{5) Automatic Teller Machine (ATM)}

Automatic Teller Machine is the most popular devise in India, which enables the customers to withdraw their money 24 hours a day 7 days a week. In addition to cash withdrawal, ATMs can be used for payment of utility bills, funds transfer between accounts, deposit of cheques and cash into accounts, balance enquiry etc.

\section{6)Tele Banking}

Tele Banking facilitates the customer to do entire non-cash related banking on telephone. Under this devise Automatic Voice Recorder is used for simpler queries and transactions. For complicated queries and transactions, manned phone terminals are used.

\section{7) Point of Sale Terminal}

Point of Sale Terminal is a hardware system for processing card payments at retail locations. It is linked online to the computerized customer information files in a bank and magnetically encoded plastic transaction card that identifies the customer to the computer. During a transaction, the customer's account is debited and the retailer's account is credited by the computer for the amount of purchase. The first point of sale system was introduced by the National Cash Register the company who registers majority of cash in the world.

\section{CONCLUSION}

Over the years, the banking sector in India has seen a number of changes. Most of the banks have begun to take an innovative step towards banking with the aim of creating more value for its customers, and consequently, the banks. Banking is no more just limited to depositing and withdrawing cash. The system of traditional banking got extinct much before the 90s.9 Banks have benefitted in several ways by adopting latest technologies such as E-banking which has resulted in reducing costs drastically and has helped generate revenue through various channels. The number of customer base has also increased because of the convenience in 'Anywhere Banking' which means availing banking services anytime anywhere at your fingertips. Digitization has reduced human error. It is possible to retrieve and examine the data anytime enabling a strong reporting system. The privatization of the India Banks has succeeded over the years as the level of NPA's has reduced and there has been a growth of foreign banks and increase in the number of services offered.

Table 1 show the peak signal to noise ratio of performance of our proposed method of watermarked image and original image with various watermark image, where our watermarked images peak signal to noise ratio has a better performance than others.

\section{REFERENCE}

[1] Banking Industry in India: Intro, Need, History, Structure, Growth and Challenges." Essays, Research Papers and Articles on Business Management, 1 Aug. 2018

[2] B, Sanli, and HobikoÄŸlu EH. "Development of Internet Banking as the Innovative Distribution Channel and Turkey Example." The Journal of Internet Banking and Commerce, Research and Reviews, 9 Oct. 2015, www.icommercecentral.com/open-access/developmentof-internet-banking-as-the-innovative-distributionchanneland-turkey-example.php?aid=62534.

[3] Sathye, Milind. "Privatization, Performance, and Efficiency: A Study of Indian Banks." Reserachgate, www.researchgate.net/publication/228337356_Privatizati on_Performance_and_Efficiency_A_Study_of_Indian_Ba nks.

[4] Craytheon." Current SLR, CRR, RBI Repo Rate, Reverse Repo, Latest, Historical Base Rate Ranju, Keshava. "Impact of Privatization on Indian Banking Sector." International Journal of Advanced Trends in Engineering and Technology, Vol. 1(1), 5 June 2017, pp. 105-107., papers.ssrn.com/sol3/papers.cfm?abstract_id=2979983.

[5] Ranju, Keshava. "Impact of Privatization on Indian Banking Sector." International Journal of Advanced Trends in Engineering and Technology, Vol. 1(1), 5 June 2017, pp. 105-107., papers.ssrn.com/sol3/papers.cfm?abstract_id=2979983.

[6] Karuppasamy, Dr. R, and Mr. C. Arul Venkadesh. "Recent Trends in Banking." MBAOnline, www.mbainfoline.com.

[7] Deolalkar, G H (2000). "The Indian Banking Sector: On the Road to Progress," available at http://www.adb.org/ Documents/Books/Rising_to_the_Challenge/India/ india_bnk.pdf, accessed on September 29, 2003 
[8] Private-owned Firms: An Empirical Analysis ofProfitability, Leverage and Labor Intensity," Financial

[9] Economics Network Working Papers

[10] Report on Trend and Progress of Banking in India (2002).Reserve Bank of India, Mumbai

[11] Arunachalam, L. and Sivasubramanian, M. (2007) 'The future of Internet Banking in India', Academic Open Internet Journal, Vol. 20. Available online at: www.acadjournal.com

[12] Gerrard, P. and Cunningham, J.B. (2005) 'The service quality of e-banks: an exploratory study', International Journal of Financial Service Management, Vol. 1, No. 1, pp.102-117. 